\title{
Data Management Communication Document
}

National Cancer Institute

\section{Source}

National Cancer Institute. Data Management Communication Document. NCI

Thesaurus. Code C115680.

Records of communications pertaining to data management. 